\title{
ANALISIS PENAWARAN JAGUNG DI JAWA TENGAH
}

\author{
Oleh : \\ Setyowati dan MeTri Sundari \\ Staf Pengajar Jurusan Sosial Ekonomi Pertanian / Agrobisnis Universitas Sebelas Maret
}

\begin{abstract}
ABSTRAK
Penelitian ini bertujuan untuk menganalisis faktor-faktor yang mempengaruhi penawaran jagung di Jawa Tengah serta untuk menganalisis tingkat kepekaan (elastisitas) penawaran jagung di Jawa Tengah. Metode dasar yang digunakan dalam penelitian ini adalah metode deskriptif. Daerah penelitian ditentukan secara sengaja sengaja (purposive) yaitu Jawa Tengah. Sedangkan jenis data yang digunakan dalam penelitian ini adalah data sekunder.Dari hasil analisis diperoleh nilai koefisien determinasi yang telah disesuaikan $\left(\mathrm{R}^{2}\right)$ yang menunjukkan proporsi sumbangan variabel-variabel bebas yang diduga berpengaruh terhadap penawaran jagung di Jawa Tengah adalah sebesar 54,6 \%. Dan dari uji $F$ diperoleh nilai $F$ hitung $(4,608)$ lebih besar daripada $F$ tabel $(3,48)$ yang berarti bahwa seluruh variabel penduga yang digunakan dalam penelitian yaitu luas areal panen jagung pada tahun yang bersangkutan, produksi jagung pada tahun sebelumnya, harga jagung pada tahun sebelumnya, harga kacang tanah pada tahun sebelumnya, harga pupuk urea serta rata-rata curah hujan selama musim tanam secara bersama-sama berpengaruh terhadap penawaran jagung di Jawa Tengah. Hasil analisis uji t menunjukkan luas areal panen jagung pada tahun yang bersangkutan (At) dan curah hujan (Wt) berpengaruh secara nyata pada tingkat kepercayaan $95 \%$ terhadap penawaran jagung di Jawa Tengah. Hal ini ditunjukkan dengan nilai probabilitas $t$ hitung masing-masing variabel bebas yang lebih besar daripada nilai $\alpha(0,05)$ pada itngkat keercayaan $95 \%$. Produksi jagung pada tahun sebelumnya (Qt-1), harga jagung pada tahun sebelumnya (Pt-1), harga kacang tanah pada tahun sebelumnya (Pst-1), dan harga pupuk urea (Put) memiliki probabilitas lebih besar $\alpha(0,05)$, hal ini berarti bahwa produksi jagung pada tahun sebelumnya (Qt-1), harga jagung pada tahun sebelumnya (Pt-1), harga kacang tanah pada tahun sebelumnya (Pst-1), dan harga pupuk urea (Put) tidak berpengaruh nyata pada tingkat kepercayaan $95 \%$ terhadap penawaran jagung di Jawa Tengah. Elastisitas penawaran jagung di Jawa Tengah dalam jangka pendek memiliki nilai elastisitas kurang dari satu yang berarti bahwa bersifat inelastis terhadap perubahan luas areal panen jagung (At), produksi jagung tahun sebelumnya (Qt-1) dan curah hujan. Hal ini berarti bahwa persentase perubahan jumlah penawaran jagung lebih kecil daripada persentase perubahan luas areal panen jagung, produksi jagung tahun sebelumnya dan curah hujan. Dalam jangka panjang penawaran jagung bersifat elastis terhadap perubahan luas areal panen jagung dan produksi jagung tahun sebelumnya jagung yang ditunjukkan dengan nilai elastisitas yang lebih dari satu. Hal ini berarti bahwa persentase perubahan jumlah penawaran jagung lebih besar daripada persentase perubahan luas areal panen jagung dan produksi jagung tahun sebelumnya. Sedangkan elastisitas jangka panjang penawaran jagung bersifat inelastis terhadap curah hujan. Hal ini berarti bahwa persentase perubahan jumlah penawaran jagung lebih kecil daripada persentase perubahan curah hujan.
\end{abstract}

Kata Kunci : ...

\section{PENDAHULUAN}

Di dalam pembangunan pertanian, subsektor tanaman pangan mempunyai posisi strategis dan penting. Peran subsektor ini adalah sebagai penghasil makanan pokok yang tidak dapat disubstitusi oleh sektor ekonomi lainnya. Sementara itu ketahanan pangan merupakan prasyarat utama bagi tercapainya ketahanan ekonomi maupun ketahanan politik. Oleh karena itu peningkatan produksi pangan untuk dapat mewujudkan pemulihan ekonomi dan mempertahankan swasembada merupakan upaya strategis untuk memantapkan ketahanan pangan sekaligus ketahanan nasional (Wibowo, 2000).

Data Susenas pada tahun 1998, diketahui bahwa jumlah penduduk Indonesia telah mencapai lebih dari 201 juta jiwa dan diproyeksikan pada tahun 2025 penduduk Indonesia berjumlah sekitar 270 jiwa (Napitupulu, 2000). Seiring dengan meningkatnya jumlah penduduk, permintaan jagung meningkat pula, hal ini terlihat dari kecenderungan meningkatnya impor dari tahun ke tahun. Meningkatnya permintaan akan jagung tersebut terutama disebabkan oleh meningkatnya kebutuhan jagung untuk bahan baku industri makanan dan industri pakan (Wibowo, 2000).

Besar kecilnya jumlah penawaran jagung dipengaruhi oleh faktor produksi dan manajemen. Terjadinya perubahan keseimbangan antara permintaan dan penawaran akan mempengaruhi perubahan harga. Harga jagung sering mengalami fluktuasi secara tak beraturan yaitu harga akan 
turun pada saat panen dan naik pada saat paceklik. Harga yang lebih baik akan merangsang petani untuk meningkatkan produksi dan produktivitasnya sehingga dapat meningkatkan penawaran jagung itu sendiri. Oleh karena itu maka penelitian ini dilakukan untuk mengetahui beberapa faktor yang mempengaruhi penawaran jagung di Wonogiri serta tingkat elastisitasnya.

Jagung merupakan komoditi tanaman pangan terpenting kedua setelah padi yang akhirakhir ini semakin meningkat pula penggunaannya sebagai pakan dan bahan baku industri. Berbagai usaha telah dilakukan untuk meningkatkan produksi jagung di Propinsi Jawa Tengah dan tampaknya telah membawa hasil nyata. Sekalipun demikian, masih banyak tantangan yang harus dihadapi untuk memperbaiki produksi jagung. Dengan teknnologi yang semakin maju, diperkirakan kebutuhan jagung bagi keperluan manusia, pakan maupun industri semakin tinggi. Banyaknya produksi jagung akan berpengaruh terhadap jumlah jumlah jagung yang ditawarkan, selanjutnya jumlah penawaran jagung akan mempengaruhi tinggi rendahnya harga. Sedangkan perubahan harga ditingkat petani mempunyai arti penting dalam merangsang peningkatan produksi dan produktivitas mereka.

Melihat potensi jagung dari sisi permintaan yang semakin meningkat, maka harus diimbangi dengan penawaran jagung yang lebih baik. Penawaran jagung sangat dipengaruhi oleh besarnya produksi yang ada dan areal tanam serta harga jagung itu sendiri. Apabila harga jagung naik, maka petani akan beramai-ramai menanam jagung sehingga luas areal tanam akan bertambah luas dan keadaan ini akan menambah jumlah penawaran yang terjadi namun pada akhirnya akan diikuti pula oleh adanya penurunan harga. Jika keadaan tersebut tidak segera diatasi maka usaha peningkatan pendapatan petani jagung akan mengalami hambatan. Harga, luas areal tanam dan jumlah produksi mempunyai hubungan yang erat. Naik turunnya harga suatu komoditi pertanian pada suatu tahun tanam akan mempengaruhi luas atau sempitnya areal tanam pada tahun berikutnya. Luas atau sempitnya areal tanam akan berpengaruh terhadap jumlah produksi yaitu produksi akan meningkat atau berkurang. Jumlah produksi yang berhasil dipanen akan berpengaruh terhadap jumlah produksi yang ditawarkan. Sedangkan jumlah penawaran akan berpengaruh terhadap harga.

Tujuan penelitian untuk mengetahui faktor-faktor yang mempengaruhi penawaran jagung di Kabupaten Wonogiri dan tingkat kepekaan (elastisitas) penawaran jagung akibat faktor-faktor yang mempengaruhinya

\section{BAHAN DAN METODE}

\section{A. Metode dasar penelitian}

Metode dasar penelitian yang digunakan adalah metode deskriptif, yaitu metode penelitian yang mempunyai sifat-sifat atau ciri-ciri :

1. Memusatkan diri pada pemecahan masalahmasalah yang ada pada masa sekarang, pada masalah-masalah

yang actual

2. Data yang dikumpulkan mula-mula disusun, dijelaskan, dan kemudian dianalisis (Surakhmad, 1994)

\section{B. Metode Penentuan Lokasi penelitian}

Lokasi penelitian dipilih secara sengaja atau purposive, yaitu cara pengambilan lokasi dengan sengaja karena alasan-alasan diketahuinya sifat-sifat dari lokasi tersebut (Surakhmad, 1994).

Penelitian mengenai penawaran jagung di ini dilaksanakan di Propinsi Jawa Tengah dengan pertimbangan bahwa propinsi ini merupakan salah satu sentral produksi jagung di Indonesia.

\section{Jenis dan Sumber data}

Data yang digunakan untuk menganalisis penawaran jagung di Kabupaten Wonogiri ini adalah data sekunder yang merupakan data berkala atau time series selama 15 tahun yaitu dari tahun 1991 sampai tahun 2006 yang berasal dari Dinas Pertanian Tanaman Pangan Propinsi Jawa Tengah dan Biro Pusat Statistik Propinsi Jawa Tengah.

\section{F. Metode Analisis}

\section{Fungsi Penawaran}

Untuk mengestimasi jumlah penawaran jagung digunakan model regresi linier berganda yang dituliskan sebagai berikut :

$$
A_{t}=b_{0}+b_{1} P_{t-1}+b_{2} R_{t}+b_{3} Q_{t-1}+b_{4} A_{t-1}+b_{5} K_{t-1}+b_{6} U_{t-1}
$$

Keterangan :

$\mathrm{A}_{\mathrm{t}} \quad$ : Jumlah penawaran pada tahun $\mathrm{t}$ (ton)

$\mathrm{P}_{\mathrm{t}-1} \quad$ : Harga jagung pada tahun sebelumnya ( $\mathrm{Rp} / \mathrm{kg})$

$\mathrm{R}_{\mathrm{t}} \quad$ : Rata-rata jumlah curah hujan pada tahun $\mathrm{t}$ $(\mathrm{mm} / \mathrm{bln})$

$\mathrm{Q}_{\mathrm{t}-1} \quad$ : Jumlah produksi pada tahun sebelumnya (ton)

$\mathrm{A}_{\mathrm{t}-1} \quad$ : Luas areal tanah pada tahun $\mathrm{t}(\mathrm{Ha})$

$\mathrm{K}_{\mathrm{t}-1} \quad$ : Harga kacang tanah pada tahun sebelumnya $(\mathrm{Rp} / \mathrm{kg})$

$\mathrm{U}_{\mathrm{t}-1} \quad$ : Harga pupuk urea pada tahun $\mathrm{t}(\mathrm{Rp} / \mathrm{kg})$

$\mathrm{b}_{0} \quad$ : Konstanta

$\mathrm{k} \quad$ : Koefisien penyesuaian

$b_{1}-b_{7} \quad$ : Koefisien regresi dari variabel bebas 
Untuk menghilangkan pengaruh perubahan harga ataupun perubahan nilai tukar uang yang terjadi, harga relatif (harga terdeflasi) dapat dicari dengan rumus :

$$
\mathrm{Ht}^{\prime}=\underline{\mathrm{IHKd}} \times \mathrm{IHKt}
$$

Dimana :

Ht' : Harga relatif jagung pada tahun $\mathrm{t}$

IHKd : Indeks harga konsumen pada tahun dasar

IHKt : Indeks harga konsumen pada tahun $\mathrm{t}$

Ht : Harga absolut jagung/sebelum terdeflasi pada tahun $\mathrm{t}$

\section{Elastisitas Penawaran}

Untuk memperoleh ukuran kuantitatif respon petani terhadap perubahan harga adalah dengan mengukur besar kecilnya perubahan harga terhadap perubahan jumlah produksi yang ditawarkan dengan menggunakan konsep elastisitas. Secara umum, elastisitas jangka pendek dirumuskan sebagai berikut :

$$
\mathrm{Ep}=\mathrm{bi} \frac{\mathrm{Xi}}{\mathrm{Y}}
$$

Keterangan :

Ep : Elastisitas penawaran jangka pendek

bi : Koefisien regresi variabel bebas ke-i

$\mathrm{Xi}$ : rata-rata nilai variabel bebas

Y : Rata-rata variabel tak bebas

Sedangkan elastisitas jangka panjang dapat diketahui setelah elastisitas jangka pendek diketahui. Elastisitas jangka panjang dirumuskan sebagai berikut :

Elastisitas jangka panjang $=\frac{\text { Elastisitas jangka pendek }}{\text { Koefisien penyesuaian }}$

Nilai koefisien penyesuaian diperoleh dari :

$$
\mathrm{k}=1-\mathrm{b}_{2} \mathrm{~A}_{\mathrm{t}-1}
$$

Keterangan :

k : Koefisien penyesuaian

$\mathrm{b}_{2} \quad$ : Koefisien regresi dari $\mathrm{A}_{\mathrm{t}-1}$

Jika di dalam perhitungan tersebut diperoleh Ep > 1 maka penawaran tersebut bersifat elastis yang berarti bahwa prosentase perubahan jumlah penawaran lebih besar daripada prosentase perubahan harga. Sedangkan Ep $<1$, maka penawaran tersebut dikatakan inelastis dimana prosentase perubahan harga lebih besar dari prosentase perubahan jumlah penawaran.

A. Variabel-variabel yang Berpengaruh Terhadap Penawaran Jagung di Jawa Tengah

Dalam penelitian yang berjudul Analisis Penawaran Jagung di Jawa Tengah, beberapa variabel yang dianggap berpengaruh terhadap perubahan penawaran jagung di Jawa Tengah adalah luas areal panen pada tahun yang bersangkutan (At), jumlah produksi jagung pada tahun sebelumnya (Qt-1), harga jagung pada tahun sebelumnya (Pt-1), harga kacang tanah pada tahun sebelumnya (Pst-1), harga pupuk urea pada tahun sebelumnya (Put-1) dan rata-rata curah hujan selama musim tanam (Wt). Dari data di atas kemudian dianalisis dengan menggunakan regresi linier berganda pada fungsi penawaran. Model persamaan regresi yang diperoleh adalah sebagai berikut :

$\mathrm{Qt}=-657784.4482+2.674030895^{*} \mathrm{~A}_{\mathrm{t}}+$ 0.6111955133* $\mathbf{Q}_{\mathrm{t}-1}+302.0719578^{*} \mathbf{P}_{\mathrm{t}-1}+$ 165.2231724* $\mathbf{P}_{\mathrm{st}-1}+184.2117003^{*} \mathbf{P}_{\mathrm{ut}}-$ $1911.730982 * \mathbf{W}_{\mathrm{t}}$

Dalam penelitian Analisis Penawaran Jagung di Jawa Tengah, variabel-variabel yang digunakan sebagai penduga dalam mempengaruhi penawaran jagung adalah luas areal panen pada tahun yang bersangkutan $\left(\mathrm{A}_{\mathrm{t}}\right)$, produksi jagung tahun sebelumnya $\left(Q_{t-1}\right)$, harga jagung tahun sebelumnya $\left(\mathrm{P}_{\mathrm{t}-1}\right)$, harga kacang tanah pada tahun sebelumnya $\left(\mathrm{P}_{\text {st- } 1}\right)$, harga pupuk urea $\left(\mathrm{P}_{\mathrm{ut}-1}\right)$, serta rata-rata curah hujan selama musim tanam $\left(\mathrm{W}_{\mathrm{t}}\right)$. Analisis menggunakan data time series dari tahun 1987 sampai dengan tahun 2006.

\section{HASIL DAN PEMBAHASAN}

Koefisien determinasi menunjukkan seberapa besar proporsi sumbangan variabel bebas secara bersama-sama terhadap variabel tak bebas. Dalam penelitian ini digunakan nilai Adjusted $R$ Square $\left(\mathrm{R}^{2}\right)$, besarnya nilai koefisien determinasi $\left(\mathrm{R}^{2}\right)$ dari hasil analisis adalah 0,546 yang berarti bahwa $54,6 \%$ variasi penawaran jagung di Jawa Tengah dapat dijelaskan oleh variabel-variabel bebas yang digunakan dalam penelitian yaitu luas areal panen jagung pada tahun yang bersangkutan, produksi jagung tahun sebelumnya, harga jagung tahun sebelumnya, harga kacang tanah tahun sebelumnya, harga pupuk urea tahun sebelumnya serta rata-rata curah hujan selama musim tanam. Sedangkan sisanya sebesar $45,4 \%$ dijelaskan oleh variabel-variabel lain di luar variabel yang diteliti. Berdasarkan hasil analisis diperoleh nilai koefisien determinasi $\left(\mathrm{R}^{2}\right)$ sebesar 0,546 yang berarti $54,6 \%$ proporsi sumbangan variabel bebas yang dapat menjelaskan variabel tak bebas. Sedangkan sisanya sebesar $45,4 \%$ dipengaruhi oleh faktor-faktor lain di luar variabel yang digunakan. Variabel-variabel lain yang sekiranya dapat mempengaruhi penawaran jagung di Jawa Tengah adalah 
penggunaan teknologi serta faktor serangan hama dan bencana alam. Oleh karena variabel-variabel tersebut sulit untuk dihitung secara kuantitatif maka tidak dimasukkan ke dalam model analisis.
Uji $\mathrm{F}$ digunakan untuk menguji apakah variabel-variabel bebas yang digunakan secara bersama-sama berpengaruh terhadap penawaran jagung di Jawa Tengah. Hasil analisis varian uji $\mathrm{F}$ secara lebih jelas dapat dilihat pada tabel 1

Tabel 1. Analisis Varian Faktor-faktor yang Berpengaruh Terhadap Penawaran Jagung di Jawa Tengah Dependent Variable: Y

Method: Least Squares

Included observations: 19

\begin{tabular}{lcccc}
\hline \hline Variable & Coefficient & Std. Error & t-Statistic & Prob. \\
\hline \hline C & -657784.4 & 1123083 & -0.585695 & 0.5689 \\
At & 2.674031 & 0.680701 & 3.928349 & 0.0020 \\
Qt-1 & 0.611196 & 0.303911 & 2.011103 & 0.0673 \\
Pt-1 & 302.0720 & 1581.083 & 0.191054 & 0.8517 \\
Pst-1 & 165.2232 & 273.8998 & 0.603225 & 0.5576 \\
Put & 184.2117 & 468.9301 & 0.392834 & 0.7013 \\
Wt & -1911.731 & 641.7231 & -2.979059 & 0.0115 \\
\hline \hline R-squared & 0.697328 & Mean dependent var & 1608264. \\
Adjusted R-squared & 0.545992 & S.D. dependent var & 294905.2 \\
S.E. of regression & 198707.5 & Akaike info criterion & 27.51437 \\
Sum squared resid & $4.74 \mathrm{E}+11$ & Schwarz criterion & 27.86232 \\
Log likelihood & -254.3865 & F-statistic & 4.607812 \\
Durbin-Watson stat & 2.148029 & Prob(F-statistic) & 0.011837 \\
\hline \hline Sumber : Analisis Data Sekunder & $=$ & &
\end{tabular}

Sumber : Analisis Data Sekunder

Berdasarkan hasil uji $\mathrm{F}$ diperoleh nilai $\mathrm{F}$ hitung sebesar 18,632 lebih besar dari nilai F hitung pada tingkat kepercayaan $95 \%$. Berdasarkan hasil tersebut maka hipotesis pertama diterima yang menyatakan diduga bahwa luas areal panen pada tahun yang bersangkutan, produksi jagung pada tahun sebelumnya, harga jagung pada tahun sebelumnya, harga kacang tanah pada tahun sebelumnya, harga pupuk urea serta rata-rata jumlah curah selama musim tanam secara bersamasama mempengaruhi penawaran jagung di Jawa Tengah.

Berdasarkan tabel. di atas dapat diketahui bahwa nilai $\mathrm{F}$ hitung sebesar 4.607812 dengan probabilitas lebih kecil dari $\alpha(0.011837)$ pada tingkat kepercayaan 95\% sehingga Ho ditolak dan Ha diterima yang berarti bahwa luas areal panen jagung pada tahun yang bersangkutan, produksi jagung pada tahun sebelumnya, harga jagung pada tahun sebelumnya, harga kacang tanah pada tahun sebelumnya, harga pupuk urea serta rata-rata curah hujan selama musim tanam secara bersama-sama berpengaruh terhadap penawaran jagung di Jawa Tengah.

Uji $\mathrm{t}$ digunakan untuk mengetahui pengaruh secara parsial masing-masing variabel bebas yang digunakan terhadap penawaran jagung di Jawa Tengah. Berdasarkan hasil analisis diperoleh hasil uji t yang ditunjukkan pada tabel 2

Tabel 2. Pengaruh Masing-masing Variabel Bebas Terhadap Penawaran Jagung di Jawa Tengah

\begin{tabular}{|l|l|l|l|}
\hline Variabel Bebas & Koefisien Regresi & t hitung & Probabilitas \\
\hline At & 2.674031 & $3.928349^{* *}$ & 0.0020 \\
\hline Qt $_{-1}$ & 0.611196 & $2.011103^{*}$ & 0.0673 \\
\hline Pt $_{1}$ & 302.0720 & $0.191054^{\text {ns }}$ & 0.8517 \\
\hline Pst- 1 & 165.2232 & $0.603225^{\text {ns }}$ & 0.5576 \\
\hline Put- 1 & 184.2117 & $0.392834^{\text {ns }}$ & 0.7013 \\
\hline Wt & -1911.731 & $-2.979059^{* *}$ & 0.0115 \\
\hline
\end{tabular}

Sumber : Analisis Data Sekunder

Keterangan :

** Nyata pada tingkat kepercayaan $95 \%$, * Nyata pada tingkat kepercayaan $90 \%$, ns Tidak nyata pada tingkat kepercayaan $95 \%$ 
Dari tabel 2 di atas dapat diketahui bahwa luas areal panen jagung pada tahun yang bersangkutan (At) dan curah hujan (Wt) berpengaruh secara nyata pada tingkat kepercayaan 95\% terhadap penawaran jagung di Jawa Tengah. Hal ini ditunjukkan dengan nilai probabilitas $t$ hitung masing-masing variabel bebas yang lebih besar daripada nilai $\alpha(0,05)$ pada itngkat keercayaan $95 \%$

Produksi jagung pada tahun sebelumnya (Qt-1), harga jagung pada tahun sebelumnya (Pt-1), harga kacang tanah pada tahun sebelumnya (Pst-1), dan harga pupuk urea (Put) memiliki probabilitas lebih besar $\alpha(0,05)$, hal ini berarti bahwa produksi jagung pada tahun sebelumnya (Qt-1), harga jagung pada tahun sebelumnya (Pt-1), harga kacang tanah pada tahun sebelumnya (Pst-1), dan harga pupuk urea (Put) tidak berpengaruh nyata pada tingkat kepercayaan $95 \%$ terhadap penawaran jagung di Jawa Tengah.

Berdasarkan hasil uji $\mathrm{t}$ diperoleh hasil bahwa luas areal panen jagung pada tahun yang bersangkutan, produksi jagung tahun sebelumnya dan curah hujan berpengaruh nyata terhadap penawaran jagung di Jawa Tengah. Sedangkan variabel harga jagung tahun sebelumnya, harga kacang tanah tahun sebelumnya dan harga pupuk urea tidak berpengaruh nyata terhadap penawaran jagung di Jawa Tengah. Dari variabel-variabel yang berpengaruh nyata terhadap penawaran jagung tersebut maka berdasarkan nilai standar koefisien regresi parsial dapat diketahui bahwa luas areal panen merupakan variabel yang paling berpengaruh terhadap penawaran jagung di Jawa Tengah

Untuk mengetahui lebih lanjut mengenai variabelvariabel bebas yang digunakan sebagai penduga dalam mempengaruhi penawaran jagung di Jawa Tengah dapat dijelaskan sebagai berikut :

\section{Elastisitas Penawaran}

Berdasarkan hasil uji $\mathrm{t}$ dapat diketahui bahwa variabel bebas yang berpengaruh nyata terhadap penawaran jagung di Jawa Tengah adalah luas areal panen jagung pada tahun yang bersangkutan (At), produksi jagung tahun sebelumnya (Qt-1), harga jagung tahun sebelumnya $\left(\mathrm{Pt}_{-1}\right)$ serta harga pupuk urea tahun sebelumnya (Put- 1 ). Untuk mengetahui besarnya nilai elastisitas penawaran dalam jangka pendek dan jangka panjang dapat dilihat pada tabel berikut :

Tabel 3. Nilai elastisitas Jangka Pendek dan Jangka Panjang Penawaran Jagung di Jawa Tengah

\begin{tabular}{|l|l|l|}
\hline \multirow{2}{*}{ Variabel } & Elastisitas \\
\cline { 2 - 3 } & Jangka Pendek & Jangka Panjang \\
\hline At & 0,955 & 2,457 \\
\hline Qt-1 & 0,595 & 1,529 \\
\hline Wt & $-0,319$ & $-0,820$ \\
\hline
\end{tabular}

Sumber : Analisis Data Sekunder

Berdasarkan tabel 3 maka dapat diketahui bahwa dalam jangka pendek penawaran jagung memiliki nilai elastisitas kurang dari satu yang berarti bahwa bersifat inelastis terhadap perubahan luas areal panen jagung (At), produksi jagung tahun sebelumnya (Qt-1) dan curah hujan. Hal ini berarti bahwa persentase perubahan jumlah penawaran jagung lebih kecil daripada persentase perubahan luas areal panen jagung, produksi jagung tahun sebelumnya dan curah hujan. Dalam jangka panjang penawaran jagung bersifat elastis terhadap perubahan luas areal panen jagung dan produksi jagung tahun sebelumnya jagung yang ditunjukkan dengan nilai elastisitas yang lebih dari satu. Hal ini berarti bahwa persentase perubahan jumlah penawaran jagung lebih besar daripada persentase perubahan luas areal panen jagung dan produksi jagung tahun sebelumnya. Sedangkan elastisitas jangka panjang penawaran jagung bersifat inelastis terhadap curah hujan. Hal ini berarti bahwa persentase perubahan jumlah penawaran jagung lebih kecil daripada persentase perubahan curah hujan.

\section{Luas Areal Panen Jagung Pada Tahun yang bersangkutan (At) \\ Variabel luas areal panen (At) berdasarkan} hasil uji $t$ pada tingkat kepercayaan 95\% berpengaruh nyata terhadap penawaran jagung di Jawa Tengah. Dalam jangka pendek luas areal panen jagung memiliki elastisitas sebesar 0,955 yang berarti bahwa persentase perubahan penawaran jagung lebih kecil daripada persentase perubahan luas areal panen. Sedangkan hubungannya bersifat positif, maksudnya bahwa apabila terjadi peningkatan luas areal panen sebesar $1 \%$ akan diikuti oleh peningkatan penawaran sebesar $0,955 \%$ dengan asumsi ceteris paribus. Atau sebaliknya apabila terjadi penurunan luas areal panen sebesar $1 \%$ maka akan diikuti dengan penurunan penawaran sebesar $0,955 \%$. Sedangkan dalam jangka panjang luas areal panen bersifat elastis dengan nilai elastisitas sebesar 2,457 yang 
berarti bałiwa perubahan penawaran jagung lebih besar daripada perubahan luas areal panen jagung. Hubungannya bersifat positif yang berarti bahwa peningkatan luas areal panen jagung sebesar $1 \%$ akan meningkatkan penawaran jagung sebesar $2,457 \%$, dan sebaliknya penurunan luas areal panen jagung sebesar $1 \%$ akan menurunkan penawaran jagung sebesar $2,457 \%$ dengan asumsi ceteris paribus. Dalam jangka pendek luas areal panen bersifat inelastis sedangkan dalam jangka panjang luas areal panen bersifat elastis. Hal ini dapat terjadi karena dalam jangka pendek reaksi petani masih bersifat seketika sehingga ketanggapan penawaran jagung akibat perubahan luas areal panen masih kecil. Sedangkan dalam jangka panjang sudah terjadi pengaturan kembali seperti halnya masuknya investasi-investasi baru dengan cara penambahan lahan untuk penanaman jagung dan cara tanam yang benar akan mempengaruhi peningkatan produksi jagung yang dihasilkan.

Ditinjau dari pernyataan hipotesis kedua yaitu diduga bahwa variabel harga jagung pada tahun sebelumnya mempunyai elastisitas paling tinggi dibandingkan variabel lain dalam mempengaruhi penawaran jagung di Jawa Tengah maka hipotesis tersebut ditolak. Luas areal panen jagung merupakan variabel yang mempunyai elastisitas tertinggi baik dalam jangka pendek maupun jangka panjang. Hal ini berarti bahwa perubahan luas areal panen akan mengakibatkan perubahan penawaran jagung yang lebih besar dibandingkan apabila terjadi perubahan pada variabel-variabel lain yang berpengaruh terhadap penawaran jagung di Jawa Tengah.

Berdasarkan nilai standar koefisien regresi parsial, luas areal panen merupakan variabel yang paling berpengaruh terhadap penawaran jagung di Jawa Tengah. Besar kecilnya produksi jagung ditentukan oleh luas sempitnya areal panen pada saat itu. Apabila luas areal panen meningkat maka produksi jagung pun juga akan meningkat, begitu pula sebaliknya. Luas areal panen jagung ditentukan oleh luas areal tanamnya. Keputusan petani untuk memperluas atau mempersempit luas areal tanamnya dapat disebabkan oleh faktor harga. Apabila harga jagung naik maka petani akan memperluas areal tanam jagung sehingga produksi jagung akan meningkat pula. Serangan hama dan bencana alam dapat pula menjadi faktor yang mempengaruhi keputusan petani dalam menggunakan lahannya. Petani akan mempersempit luas areal tanam jagung apabila terjadi serangan hama karena dapat mengakibatkan gagal panen, akibatnya produksi jagung menjadi menurun akibat berkurangnya petani yang menanam jagung.

Produksi jagung di Jawa Tengah sering mengalami pasang surut. Hal ini dapat terjadi sebagai akibat perubahan areal pertanaman jagung. Salah satu sebab dari perubahan areal ini adalah penggunaan areal tanam untuk usaha lain, sehingga areal pertanaman berkurang. Namun demikian selama teknologi pembenihan selalu dapat menemukan varietas-varietas unggul sebagai imbangan berkurangnya lahan, maka totalitas produksi tidak akan terlalu berubah. Tetapi pada kenyataannya di Jawa Tengah penggunaan bibit hibrida masih jarang dilakukan oleh karena kendala harga benih yang mahal serta teknik produksi yang lebih rumit. Oleh karena itu luas areal panen jagung masih merupakan faktor yang mempengaruhi banyaknya produksi jagung yang dihasilkan.

\section{Produksi Jagung Pada Tahun Sebelumnya (Qt- 1)}

Variabel produksi jagung tahun sebelumnya (Qt-1) berdasarkan analisis uji $t$ diperoleh nilai t hitung sebesar 2,011 dengan nilai probabilitas 0,067 lebih kecil daripada nilai $\alpha$ pada taraf kepercayaan $90 \%$ yang berarti bahwa produksi jagung tahun sebelumnya berpengaruh nyata terhadap penawaran jagung di Jawa Tengah. Dalam pengukuran elastisitas diperoleh nilai elastisitas jangka pendek sebesar 0,595 yang berarti bahwa perubahan penawaran jagung tahun sebelumnya lebih kecil daripada perubahan jumlah produksi jagung dengan hubungan yang positif yaitu peningkatan jumlah produksi jagung tahun sebelumnya sebesar $1 \%$ akan meningkatkan penawaran jagung sebanyak $0,595 \%$. Sedangkan dalam jangka panjang perubahan produksi jagung tahun sebelumnya bersifat elastis terhadap perubahan penawaran jagung. Diperoleh nilai elastisitas jangka panjang sebesar 1,529 yang berarti bahwa perubahan penawaran jagung lebih besar daripada perubahan luas areal panen jagung. Variabel jumlah produksi jagung yang berpengaruh nyata terhadap penawaran jagung di Jawa Tengah menunjukkan bahwa petani mendasarkan pada prinsip product oriented sehingga keputusan dalam penawaran jagung dengan mempertimbangkan produksi jagung tahun sebelumnya. Peningkatan jumlah produksi jagung pada tahun sebelumnya akan mendorong petani untuk meningkatkan penawaran jagung dengan harapan akan memperoleh keuntungan yang lebih besar dengan produksi yang lebih banyak.

Pada kenyataannya tingkat produksi sektor pertanian sangat dipengaruhi oleh faktorfaktor yang berada diluar kemampuan para petani untuk mengendalikannya. Pada umumnya produksi hasil pertanian selalu berubah-ubah dari satu musim ke musim lainnya. Perubahan musiman ini terutama dipengaruhi oleh keadaan cuaca, iklim, dan faktorfaktor alamiah yang lain. Sehingga selama kondisi 
alam masih mendukung maka kemampuan petani untuk dapat memproduksi jagung pada suatu tahun dapat menjadi acuan untuk menentukan berapa jumlah produksi jagung yang akan dihasilkan pada tahuin berikutnya.

\section{Harga Jagung Pada Tahun Sebelumnya (Pt- 1 )}

Variabel harga jagung pada tahun sebelumnya dalam analisis uji $\mathrm{t}$ diperoleh nilai $\mathrm{t}$ hitung sebesar 0,191 dengan nilai probabilitas 0,852 lebih besar daripada nilai $\alpha$ pada taraf kepercayaan 95\% yang berarti bahwa variabel harga jagung tidak berpengaruh nyata terhadap penawaran jagung di Jawa Tengah. Harga selalu dipandang sebagai faktor yang sangat penting dalam menentukan penawaran. Oleh sebab itu teori penawaran terutama menumpukan perhatiannya pada keadaan hubungan diantara tingkat harga dengan jumlah barang yang ditawarkan. Akan tetapi berdasarkan analisis lebih lanjut diperoleh hasil bahwa yang memiliki elastisitas tertinggi adalah luas areal panen jagung. Hal ini berarti bahwa harga jagung tahun sebelumnya bukan sebagai variabel yang paling berpengaruh terhadap penawaran jagung di Jawa Tengah.

Perubahan harga yang terjadi pada tahun sebelumnya ternyata tidak mempengaruhi keputusan petani untuk menambah atau mengurangi jumlah yang ditawarkan karena harga-harga jagung relative stabil kalaupun ada kenaikan atau penurunan tidak terlalu tinggi jika dihitung dengan harga riilnya. Harga yang tinggi akan mendorong petani untuk meningkatkan penawarannya dengan harapan harga akan terus naik sehingga produksi akan bertambah. Sebaliknya apabila harga turun maka petani akan malas untuk untuk memproduksi sehingga akan mengurangi jumlah yang ditawarkan pada tahun berikutnya. Oleh karena pengelolaan jagung yang semakin baik, petani mulai memperhitungkan manfaat dan keuntungan produksi, maka secara tidak langsung petani telah menerapkan ekonomi produksi pertanian.

Pada saat ini kecenderungan harga jagung dalam negeri lebih tinggi daripada harga di pasaran dunia. Harga jagung lokal di pasaran dunia mencapai sekitar US \$ 197,70/ton, sedangkan harga jagung di pasaran London sebesar US \$ 133,75/ton. Sehingga dalam kaitan ini produksi jagung dalam negeri memiliki harga dengan daya saing tinggi di pasaran luar negeri. Tetapi pada kenyataannya harga jagung di Jawa Tengah selama enam belas tahun yang terakhir cenderung mengalami penurunan. Hal ini karena produksi yang belum stabil sehingga harus bersaing dengan produk impor yang lebih dapat terjaga kontinuitasnya. Apabila hal ini terus berlanjut maka jagung lokal akan kalah bersaing dengan jagung impor. Akibatnya harga jagung menjadi semakin menurun sehingga produksi jagung juga semakin menurun.

\section{Harga Kacang Tanah Pada Tahun Sebelumnya (Pst-1)}

Variabel harga kacang tanah pada tahun sebelumnya berdasarkan perhitungan uji t diperoleh nilai $t$ hitung sebesar 0,603 dengan nilai probabilitas 0,558 lebih besar daripada nilai $\alpha$ pada taraf kepercayaan $95 \%$ yang berarti bahwa variabel harga kacang tanah tidak berpengaruh nyata terhadap penawaran jagung di Jawa Tengah. Pada umumnya di wilayah Jawa Tengah penanaman jagung dapat dilakukan di lahan tegalan maupun sawah. Di beberapa sentra produksi jagung di Jawa Tengah seperti di Grobogan dan Wonogiri tanaman jagung merupakan tanaman yang utama sehingga penurunan ataupun kenaikan tanaman palawija lain yang dapat pula ditanam di wilayah tersebut tidak mempunyai pengaruh yang berarti terhadap keputusan petani untuk menambah atau mengurangi penawaran jagung pada tahun berikutnya. Hal ini terkait dengan pola kebiasaan petani untuk menanam jagung sehingga meskipun harga barang substitusi lain dalam hal ini kacang tanah meningkat maka tidak akan mengubah pola tanam petani untuk mengganti jagung dengan kacang tanah. Selain karena kebiasaan juga karena kebisaan petani dalam menanam jagung selama beberapa tahun sehingga petani malas untuk mengganti jagung dengan tanaman lain karena konsekuensinya juga harus mengubah cara-cara penanamannya.

\section{Harga Pupuk Urea Pada Tahun Sebelumnya (Put-1)}

Variabel harga pupuk urea pada tahun sebelumnya bedasarkan uji t diperoleh nilai t hitung sebesar 0,393 dengan nilai probabilitas 0,701 lebih besar daripada nilai $\alpha$ pada taraf kepercayaan $95 \%$ yang berarti bahwa variabel pupuk urea tidak berpengaruh nyata terhadap penawaran jagung di Jawa Tengah. Pupuk urea merupakan input yang paling banyak dikeluarkan oleh petani juka dibandingkan dengan jenis pupuk yang lain seperti SP 36 dan KCL.. Hal ini karena pupuk urea merupakan input yang diberikan pada tanaman jagung dalam dosis yang lebih banyak dibandingkan pupuk $\mathrm{KCl}$ dan SP36, yaitu sebanyak $75 \%$ penggunaanya dari keseluruhan pupuk yang diperlukan. Pemupukan pada tanaman jagung sebaiknya dilakukan pada saat penanaman, umur 3 minggu dan umur 6 minggu. Selama ini terjadi kesalahan petani dalam penggunaan pupuk untuk tanaman jagung. Kebiasaan petani memberikan pupuk secara sekaligus pada awal penanaman. Hal ini menjadi tidak efektif karena pupuk urea yang 
mengandung unsur $\mathrm{N}$ yang bersifat mudah tercuci selain itu pemberian pupuk yang berlebihan akan membuat tanah menjadi jenuh sehingga produksi tidak optimal. Peningkatan harga pupuk urea tidak mempengaruhi petani dalam penggunaan input karena penggunaan urea untuk tanaman jagung sidah menjadi kebiasaan mereka sehingga meskipun terjadai perubahan harga pupuk urea mereka tetap menggunakan pupuk tersebut.

\section{Rata-rata Curah Hujan Selama Musim Tanam (W)}

Variabel rata-rata curah hujan selama musim tanam berdasarkan uji $t$ mempunyai nilai $t$ hitung sebesar $-2,979$ dengan nilai probabilitas 0,012 lebih kecil daripada nilai $\alpha$ pada taraf kepercayaan $95 \%$ yang berarti bahwa variabel ratarata curah hujan berpengaruh nyata terhadap penawaran jagung di Jawa Tengah. Selama tahun 1987-2003 perubahan curah hujan di Jawa Tengah berpengaruh terhadap perubahan penawaran jagung di Jawa tengah karena cuarah hujan yang sangat tinggi menyebabkan kelembaban yang tinggi sehingga terjadi serangan hama dan penyakit yang akan mempengaruhi penawaran jagung. Tanaman jagung cocok ditanam di Indonesia, karena kondisi tanah dan iklim yang sesuai. Di samping itu tanaman jagung tidak banyak menuntut persyaratan tumbuh serta pemeliharaannya pun lebih mudah. Tanaman jagung dapat ditanam di seluruh wilayah di Jawa Tengah dengan rata-rata curah hujan yang beragam di tiap wilayah karena jagung dapat tumbuh baik di lahan kering maupun lahan yang subur. Pada umumnya musim tanam jagung berlangsung selama bulan Oktober sampai dengan Maret. Hal ini didasarkan pada penanaman jagung yang dilakukan pada awal musim penghujan. Kebutuhan tanaman jagung akan banyaknya curah hujan hanya pada saat awal tanam, selanjutnya banyak sedikitnya curah hujan tidak begitu mempengaruhi produksi jagung. Setelah penanaman, jagung membutuhkan pengairan yang cukup pada saat pembungaan (45-55 hari) dan pengisian biji (60-80 hari). Oleh karena tanaman jagung tidak membutuhkan curah hujan yang banyak dan bahkan cenderung lebih cocok jika ditanam di daerah yang kering sehingga naik turunnya rata-rata curah hujan selama musim tanam jagung mempengaruhi banyak sedikitnya penawaran jagung yang akan dilakukan oleh petani pada tahun berikutnya.

\section{KESIMPULAN DAN SARAN}

\section{Kesimpulan}

1. Luas areal panen jagung pada tahun yang bersangkutan, produksi jagung tahun sebelumnya dan rata - rata curah hujan pada musim tanam merupakan variabel-variabel yang mempengaruhi penawaran jagung di Jawa Tengah.

2. Luas areal panen jagung pada tahun yang bersangkutan merupakan variabel yan paling berpengaruh terhadap penawaran jagung di Jawa Tengah.

3. Dalam jangka pendek penawaran jagung di Jawa Tengah bersifat inelastis terhadap luas areal panen jagung pada tahun yang bersangkutan, produksi jagung tahun sebelumnya dan rata-rata curah hujan pada musim tanam. Hal ini berarti bahwa persentase perubahan jumlah penawaran lebih kecil daripada persentase perubahan variabel-variabel yang mempengaruhinya.

4. Dalam jangka panjang penawaran jagung di Jawa Tengah bersifat elastis terhadap luas areal panen jagung tahun yang bersangkutan dan produksi jagung tahun sebelumnya yang berarti bahwa persentase perubahan penawaran lebih besar daripada persentase perubahan variabel yang berpengaruh serta bersifat inelastis terhadap rata-rata curah hujan pada musim tanam..

\section{Saran}

1. Luas areal panen merupakan variabel yang paling berpengaruh terhadap penawaran jagung di Jawa Tengah sehingga diperlukan peningkatan luas areal panen jagung dengan cara pemanfaatan lahan kering maupun lahan yang sudah tidak produktif untuk diusahakan tanaman jagung..

2. Produksi jagung tahun sebelumnya merupakan variabel yang berpengaruh terhadap penawaran jagung di Jawa Tengah. Oleh karena itu perlu diupayakan peningkatan produksi jagung dengan penggunaan bibit unggul dimana memiliki hasil produksi yang tinggi dan mempunyai ketahanan yang tinggi terhadap serangan penyakit. 


\section{DAFTAR PUSTAKA}

AAK, 1999. Teknik Bercocok Tanam Jagung. Kanisius. Yogyakarta.

Ahmad, Dwi Fahrudin Ali. 2003. Respon Penawaran Jagung di Kabupaten Gunungkidul. Skripsi Fakultas Pertanian Universitas Sebelas Maret. Surakarta.

Boediono, 1992. Ekonomi Mikro. BPFE UGM. Yogyakarta.

BPS. 2003. Jawa Tengah Dalam Angka Tahun 2003. Biro Pusat Statistik. Semarang.

Dajan, A. 1983. Pengantar Metode Statistik. LP3ES. Jakarta.

Eny Nuridah, 2004. Analisis Penawaran Ubi Kayu di Kabuipaten Wonogiri. Skripsi Fakultas Pertanian Universitas Sebelas Maret. Surakarta.
Gathak, S. dan Ingershent, K., 1984.Agriculture and Economic Development. Harverter Press. Great Britain.

Gujarati, Damodar. 1997. Ekonometrika Dasar. Erlangga Jakarta.

Listiyani, 2001. Analisis Penawaran Ubi Kayu di Kabupaten Gunung Kidul. Jurnal Ilmiah Sosial Ekonomi Pertanian.

Napitulu, 2000. Bunga Rampai Pemikiran Menuju Ketahanan Pangan. Pustaka Sinar Harapan. Jakarta.

Riyatun, ND. 2004. Analisis Penawaran Gaplek di Kabupaten Wonogiri. Skripsi S1. Fakultas Pertanian UNS Tidak Dipublikasikan.

Surakhmad, W. 1994. Pengantar Penelitian Ilmiah: Dasar, Metode dan Teknik. Tarsito. Bandung.

Wibowo, Rudi. 2000. Pertanian dan Pangan. Pustaka Sinar Harapan. Jakarta. 